\title{
Tillage Effects on Corn Soil-plant-water Continuum in Alfisols of Southern Ohio
}

\author{
Meharban Singh Kahlon ${ }^{1,3}$, Norman Fausey ${ }^{2} \&$ Rattan Lal $^{3}$ \\ ${ }^{1}$ Department of Soil Science, PAU, Ludhiana, Punjab, India \\ (Formerly, a visiting scholar at the Carbon Management and Sequestration Center, OSU, Columbus, Ohio, USA \\ in $2010-2011)$. \\ ${ }^{2}$ USDA/ ARS-Soil Drainage Research Unit, Woody Hayes Drive, Columbus, Ohio \\ ${ }^{3}$ Carbon Management and Sequestration Center, The Ohio State University, Columbus, Ohio \\ Correspondence: Meharban Singh Kahlon, Department of Soil Science, PAU, Ludhiana 141004, Punjab, India. \\ Tel: 1-161-256-4410. E-mail: dr.mskahlon@rediffmail.com
}

$\begin{aligned} & \text { Received: May 9, } 2012 \quad \text { Accepted: May 25, } 2012 \quad \text { Online Published: August 24, } 2012 \\ & \text { doi:10.5539/jas.v4n10p35 }\end{aligned} \quad$ URL: http://dx.doi.org/10.5539/jas.v4n10p35

\begin{abstract}
Tillage alters soil physical properties and impacts soil water regime, crop's relative water content (RWC), and root distribution. Thus, a field study was conducted to characterize and correlate root distribution and assess RWC of corn (Zea mays L.) with soil physical properties under two tillage systems i.e. no-till (NT), and conventional tillage (CT). The RWC, determined four times during a course of the day at two growth stages (V8, i.e. 60 days after planting; and R2, i.e. 90 days after planting), was significantly different $(\mathrm{P}<0.05)$ among two tillage treatments. Corn grown under NT had significantly higher RWC than that under CT during both growth stages. At the V8 growth stage, the RWC ranged from 73.2 to $95.4 \%$ under NT compared with 60.9 to $89.6 \%$ under CT. Further, during the afternoon measurements, RWC was $15 \%$ higher under NT than CT. A similar trend was observed during the R2 growth stage but with lesser RWC values probably due to the lower soil water content at that time. Higher root mass density (RMD) i.e. $0.50 \mathrm{Mg} \mathrm{m}^{-3}$ was measured in $0-10 \mathrm{~cm}$ depth under NT than under CT $\left(0.34 \mathrm{Mg} \mathrm{m}^{-3}\right)$, and the opposite was true for 10-20 $\mathrm{cm}$ depth. Due to the presence of a compacted layer (plow pan) in CT, roots were concentrated mostly in 10-20 cm depth. Further, higher RMD was measured along the row than within row.
\end{abstract}

Keywords: relative water content, corn root distribution, soil water content, moisture stress, no till, conventional tillage

\section{Abbreviations}

$\mathrm{CT}=$ conventional tillage $\mathrm{NT}=$ no-till; $\mathrm{PR}=$ penetration resistance of soil; $\mathrm{RMD}=$ root mass density $; \mathrm{RWC}=$ relative water content of leaves.

\section{Introduction}

Understanding the physiological aspects of crop response to soil water deficit is important to identifying management options for optimizing agronomic production. Leaf water status is one of the most sensitive and readily measurable parameters for assessing the impact of drought stress (Malarvizhi et al., 2010). Maintenance of higher leaf water potential under drought is important to stabilizing physiological processes and agronomic yield (Kumar \& Kujur, 2003). Thus, monitoring soil-water-plant relations is an important strategy of an efficient crop production system. The water status of a plant can be assessed on the basis of its water content or on the energy status of water in the plant (Kirkham, 2005; Guiterrez et al., 2010).

The relative water content (RWC) technique, formerly known as relative turgidity, was originally described by Weatherley $(1950,1951)$ and is widely accepted as a reproducible and meaningful index of plant water status (Barrs \& Weatherley, 1962; Barrs, 1968; Esparza-Rivera et al., 2006). Leaf tissues are commonly used for RWC determination, which is a useful indicator of the water status of a plant, essentially because it expresses the absolute amount of water which the plant requires to attain full saturation, i.e. turgidity (Gonzalez \& Gonzalez-Vilar, 2001). Leaf water status is related to several leaf physiological variables, such as leaf turgor, growth, stomatal conductance, transpiration, photosynthesis and respiration (Kramer \& Boyer, 1995). Leaf water 
content is used to quantify the water deficits in leaf tissues. Flexas et al. (2006) observed that leaf and shoot RWC decreased by $75 \%$ under water stress. Similar observations were also reported by Siddique et al. (2000); Tatar and Gevrek (2008) and Keyvan (2010). Measurements of water content expressed on a tissue fresh or dry mass basis have been mostly replaced by those based on the maximum amount of water a plant tissue can hold. These measurements are referred to as RWC (Equation 1).

$$
\mathrm{RWC}=\frac{\mathrm{FW}-\mathrm{DW}}{\mathrm{TW}-\mathrm{DW}} \times 100
$$

where, FW, DW, and TW are the fresh, dry and turgid weights of the leaf tissue, respectively. Sometimes, the relationship between leaf water potential $(\psi)$ and its RWC is used for evaluation of the magnitude of water deficit in the plant tissues and cells, and for predicting tissues resistant to desiccation resulting from the water deficit (Ferrat \& Lovatt, 1999; Neyestani \& Azimzadeh, 2003; Khan \& Stoddard, 2005; Aminzadeh \& Eshghi, 2006).

Drought stress is the largest single factor limiting crop productivity globally (Pennisi, 2008), and is influenced by tillage because of its impact on rooting depth and root density distribution (Dwyer et al., 1988; Barber \& Kovar, 1991). The distribution of water within the soil profile, an important determinant of corn root distribution, is also affected by tillage (Lahai \& Ekanayake, 2009). Rooting is often shallower in no-till (NT) than in conventional tillage (CT) because of favorable soil water conditions (Vyn, 2008). Higher soil water storage is normally observed under NT as compared to CT (Diaz Zorita et al., 2002; He et al., 2006; Bhattacharyya et al., 2008), and higher root length density (RLD) is observed under straw mulch than unmulched plots (Hossain et al., 2008). Mechanical impedance, the resistance offered by the soil matrix against deformation by a growing root, is also a major factor inhibiting root growth (Amato \& Ritchie, 2002; Duruoha et al., 2007). Diaz-Zorita et al. (2005) observed quadratic response of RLD decrease with increase in soil bulk density. Root elongation occurs when root pressure exceeds mechanical impedance. In general, soil compaction inhibits plant root growth through increased mechanical resistance, and altered water and nutrient supply (Himmelbauer et al., 2010). Compaction in one portion of the soil profile may decrease RLD in underlying non-compacted layers. Taboada and Alvarez (2008) observed 40-80\% decrease in root abundance below $10 \mathrm{~cm}$ depth under CT. In general, root elongation rate decreases in response to both increasing penetrometer resistance and decreasing matric potential of soil (Bengough et al., 2011). In this regard surface soil properties are more important than tillage itself in terms of root growth, which in compacted soil is restricted when macropores are absent (Micucci \& Taboada, 2006). If macropores exist, preferential root growth occurs resulting in a clustered root system (Logsdon \& Allmaras, 1991; Tardieu, 1994). Root growth can be restricted due to increase in penetration resistance, which primarily results from increase in tension in water film between the soil particles on drying (Whalley et al., 2005; Whitmore \& Whalley, 2009; Whalley et al., 2005; Mckenzie et al., 2009; White \& Kirkgaard, 2010; Yamaguchi \& Sharp, 2010). The data presented in the literature on root distribution as affected by NT and CT are not consistent. Some have reported that root length and weight may be more prolific under NT than CT (Newell \& Wilhem, 1987; De Vita et al., 2007; Iijima et al., 2007; Martinez et al., 2008), others have reported just the opposite response (McGonigle \& Miller, 1996; Karunatilake et al., 2000), and yet some have observed similar root distribution under the two tillage systems (Raczkowski, 1988; Hughes et al., 1992).

There is a lack of process and effect-oriented research data regarding relationship between RWC and root mass distribution of corn with soil water status and mechanical impedance under different tillage practices. Therefore, the objective of this field experiment was to study variations in RWC and RMD under NT and CT practices. The study was designed to test the hypothesis that NT improves mechanical and hydrological characteristics of the soil which enhances RWC, stomatal opening and RMD as compared to CT.

\section{Materials and Methods}

\subsection{Site}

The field experiment was conducted on Omulga fine silty Oxyaquic Fragiudalfs at the South Centers of the Ohio Agricultural Research and Development Center (OARDC) at Piketon, OH (39.13 N, $83.01 \mathrm{~W} ; 176 \mathrm{~m}$ above mean sea level). The soils are moderately drained and drainage pipes are installed at lower soil depths in each plot. The soil has $\mathrm{pH}$, electrical conductivity $\left(\mathrm{dS} \mathrm{m}^{-1}\right)$, organic carbon (\%), total carbon (\%) and total porosity (\%) of $6.2,0.2,1.3,0.45$ and 44.6 respectively. The climate of the region is temperate and on average the highest and the lowest temperature recorded were 18.5 and $6.1{ }^{\circ} \mathrm{C}$ (with an overall average of $12.3{ }^{\circ} \mathrm{C}$ ) during the study year. The annual rainfall of the region is $800 \mathrm{~mm}$ (www.oardc.ohio-state.edu/weather/). A total of $490 \mathrm{~mm}$ of rainfall was received during the crop growing season from May to September. The experimental field is situated 
on land with a gentle slope gradient of $\sim 2 \%$. Individual plots with NT and CT have been managed under continuous corn since 2004. The CT plots were moldboard plowed followed by disking twice every season before sowing, where as the soil under NT plots was maintained undisturbed.

\subsection{Experimental Design}

The experiment was laid out as a Randomized Complete Block Design (RCBD), with three replications, with the individual plot size of $15 \times 30 \mathrm{~m}$. A buffer zone of $15 \mathrm{~m}$ was maintained between adjacent plots. The corn was planted in the second week of May with a seeding rate of 67400 seeds per ha and row to row spacing of $75 \mathrm{~cm}$. With the exception of tillage, other crop management practices were similar in all plots. During the 2010 growing season, measurements and samples were obtained from each plot to quantify the soil-plant-water status according to the procedures described below.

\subsection{Determination of Volumetric Soil Moisture Content $(\theta)$, Bulk Density $\left(\rho_{b}\right)$ and Soil Matric Potential $(\Phi)$}

Soil samples for determination of gravimetric soil moisture content $(\omega)$ were obtained in triplicate by a tube sampler ( $2.2 \mathrm{~cm}$ diameter) between the corn rows. Measurement of $\omega$ was made at $10 \mathrm{~cm}$ increment to $90 \mathrm{~cm}$ depth at V8 and R2 growth stages. Soil samples were oven dried at $105^{\circ} \mathrm{C}$ for 24 hours. Undisturbed soil cores were used for $\rho_{\mathrm{b}}$ determinations (Blake and Hartge, 1986). The volumetric soil moisture content $(\theta)$ was computed from the $\omega$ and $\rho_{\mathrm{b}}$ values as follows: $\theta=\omega . \rho_{\mathrm{b}} / \rho_{\mathrm{w}}$, where, $\rho_{\mathrm{w}}$ is density of water. The $\Phi$ was measured by installing tensiometers at 20,40,60 and $80 \mathrm{~cm}$ soil depths. Tensiometers equipped with suction gauges and calibrated in KPa were installed between the rows.

\subsection{Determination of Soil Penetration Resistance (PR)}

Soil PR was measured by a hand-held digital cone (12.8 mm diameter) penetrometer (Field Scout, SC 900 Soil Compaction Meter; Spectrum Technologies, Inc., Plainfield, IL, USA) at four randomly selected locations within a plot. Soil PR readings were recorded at 15,30 and $45 \mathrm{~cm}$ depths. The measurements were made in the beginning of the experiment along with simultaneous measurements of soil moisture content.

\subsection{Determination of Relative Water Content (RWC) and Stomatal Closure Time}

The RWC was determined according to the method described by Barrs and Weatherley (1962) and later modified by Esparza-Rivera et al. (2006) (See Equation 1). Three plants were randomly sampled from each plot to determine RWC of leaves at V8 and R2 growth stages of corn. The RWC determination was accomplished by excising $1 \mathrm{~cm}$ discs from the uppermost, medium and lower leaves with two discs from each leaf, thus making a total of 6 discs per plant. These disks were collected in plastic vials and weighed immediately, providing a measure of fresh weight (FW). After weighing, the disks were soaked in de-ionized water for $4 \mathrm{~h}$ and then weighed again to obtain a fully turgid weight (TW). Finally, the leaf discs were dried at $80{ }^{\circ} \mathrm{C}$ for $24 \mathrm{hrs}$ and weighed to obtain the dry weight (DW). For determining the stomatal closure time, the leave discs collected in triplicate from NT and CT plots were air dried in the lab and weighed at regular time intervals of 15 minutes until the constant weight.

\subsection{Determination of Root Mass Density (RMD)}

The RMD was measured in triplicate up to $90 \mathrm{~cm}$ depth using a tube sampler of $2.2 \mathrm{~cm}$ diameter at $15 \mathrm{~cm}$ distance along and across the corn rows. Roots from all treatments were sampled during the R2 growth stage, when maximum root mass was developed. Cores were divided into $10 \mathrm{~cm}$ depth increments. A soil sample was placed in a clean 5 liter plastic container. About 2 liters of clean water was gently poured into the container while slowly stirring the soil by hand to loosen the roots from soil and floating the roots. The supernatant was carefully passed through a pair of sieves with mesh size of $0.5 \mathrm{~mm}$ and $0.29 \mathrm{~mm}$ to capture all the roots. The captured root material in the sieves was washed again to remove any remaining soil. The material in the sieves was transferred to a basin with clean water for ease of separating live and dead roots and any other materials. Live roots were distinguished by their light color and flexible rather than friable nature. A magnifying glass and pair of forceps were used to pick out the live roots. These roots were then transferred into small petridishes and dried in an oven at $60{ }^{\circ} \mathrm{C}$ for 48 hours. The roots were weighed on a four digit balance and the RMD was calculated as the ratio of dry mass of roots and the core volume.

\subsection{Exponential Equations for RMD Estimation}

The RMD data for different depths were fitted to an exponential equation:

$$
\mathrm{Y}=\mathrm{Yo} \mathrm{e}^{-\mathrm{BX}}
$$

and a modified exponential equation (Dwyer et al., 1995) as: 


$$
\mathrm{Y}=\mathrm{Yo} \mathrm{e}^{-\mathrm{BX}}+\mathrm{C}
$$

where, $\mathrm{Y}$ is $\mathrm{RMD}\left(\mathrm{mg} \mathrm{cm}^{-3}\right)$, Yo is RMD extrapolated to $\mathrm{X}=0, \mathrm{~B}$ is a shape coefficient, $C$ is a coefficient that represents the RMD $\left(\mathrm{mg} \mathrm{cm}^{-3}\right)$ in the deepest increment, and $\mathrm{X}$ is soil depth $(\mathrm{cm})$. Data were fitted to both equations to determine the one that best represented RMD distribution with the depth.

\subsection{Statistical Analysis}

Statistical analysis was performed using one way ANOVA test and CPCS1 program (Cheema and Singh, 1990). Mean separation among treatments was obtained using the least significant difference (LSD) test at $\mathrm{P}<0.05$.

\section{Results}

\subsection{Leaf RWC as Affected by Tillage and Time of Measurement}

The RWC of leaves varied significantly $(\mathrm{P}<0.05)$ among tillage treatments as well as the times of measurement during a particular day. The RWC was higher during the morning $(800 \mathrm{hr})$, and progressively decreased during the rest of the day (i.e., 1100, 1400, $1700 \mathrm{hrs}$ ). During V8 growth stage the RWC ranged from 95.4 to $73.2 \%$ in NT and 89.6 to $60.9 \%$ under CT for measurements made at 800 and $1700 \mathrm{hrs}$ respectively (Table 1). Significant differences in RWC were observed for measurements made at $1700 \mathrm{hrs}$, when RWC was $15 \%$ more in NT than in CT. Relatively a stronger decline in RWC was observed in CT than in NT in the afternoon. A reduction in RWC from 74.1 to $60.9 \%$ was observed under CT, compared with a decrease from 78.1 to $73.2 \%$ in NT for measurements made at 1400 and $1700 \mathrm{hrs}$, respectively. Similar observations were recorded during the R2 growth stage (Table 2).

Table 1. Tillage effects on leaf relative water content (\%) at V8 growth stage of corn

\begin{tabular}{lllll}
\hline \multirow{2}{*}{ Tillage treatment } & \multicolumn{4}{l}{ Time of measurements (hrs) } \\
\cline { 2 - 5 } & 0800 & 1100 & 1400 & 1700 \\
\hline NT & 95.4 & 80.8 & 78.1 & 73.2 \\
CT & 89.6 & 78.6 & 74.1 & 60.9 \\
LSD $(<0.05)$ & Tillage $=0.48$ & \\
& Time $=0.68$ \\
& \multicolumn{4}{l}{ Tillage $\times$ Time $=0.96$} \\
\hline
\end{tabular}

$(\mathrm{NT}=$ no-till; $\mathrm{CT}=$ conventional tillage $)$

Table 2. Tillage effects on leaf relative water content (\%) at R2 growth stage of corn

\begin{tabular}{lllll}
\hline Tillage treatment & \multicolumn{4}{l}{ Time of measurements $(\mathrm{hrs})$} \\
\cline { 2 - 5 } & 0800 & 1100 & 1400 & 1700 \\
\hline NT & 82.6 & 72.1 & 65.9 & 60.3 \\
CT & 80.9 & 69.6 & 62.5 & 51.4 \\
LSD $(<0.05)$ & Tillage $=2.21$ & \\
& Time $=1.56$ & \\
& & Tillage $\times$ Time $=$ NS \\
\end{tabular}

(NT= no-till; $\mathrm{CT}=$ conventional tillage $)$

The leaf RWC was significantly correlated with the matric potential $(\Phi)$ of the soil (Figure 1). There was a significant decrease in RWC from 95.4 to $82.6 \%$ (NT) and from 89.6 to $80.9 \%$ (CT) with increase in $\Phi(\mathrm{KPa})$ \{means more negative or decreasing soil water content value\} from 59 to 70 (NT) and 68 to 77 (CT) for the measurements made at 800 hrs during V8 and R2 growth stages, respectively. During the afternoon, there was a three times more decrease in RWC value as compared to the measurements made during the morning. Similarly, significant correlations were observed between water content of the soil ( $\omega$ ) and RWC (Figure 2). The maximum variation in $\omega$ was observed between NT (23.6\%) at V8 growth stage and CT (14.1\%) at R2 growth stage. The RWC decreased by $44 \%$ with $8 \%$ decrease in $\omega$. 


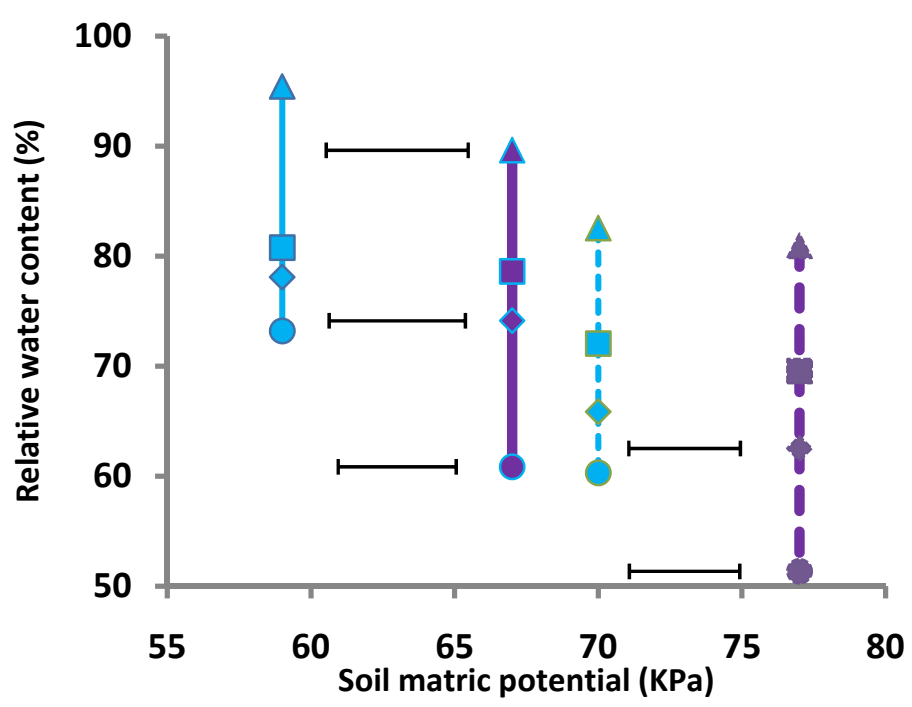

Figure 1. Relative water content as affected by no-till (light colored lines), conventional tillage (dark colored lines) and soil matric potential at V8 (solid lines) and R2 (dashed lines) growth stages. (Different markers $\mathbf{\Lambda}, \mathbf{\square}$,

- and •represent measurements made at 800, 1100, 1400 and $1700 \mathrm{hrs})$. Bars show LSD $(<0.05)$ values

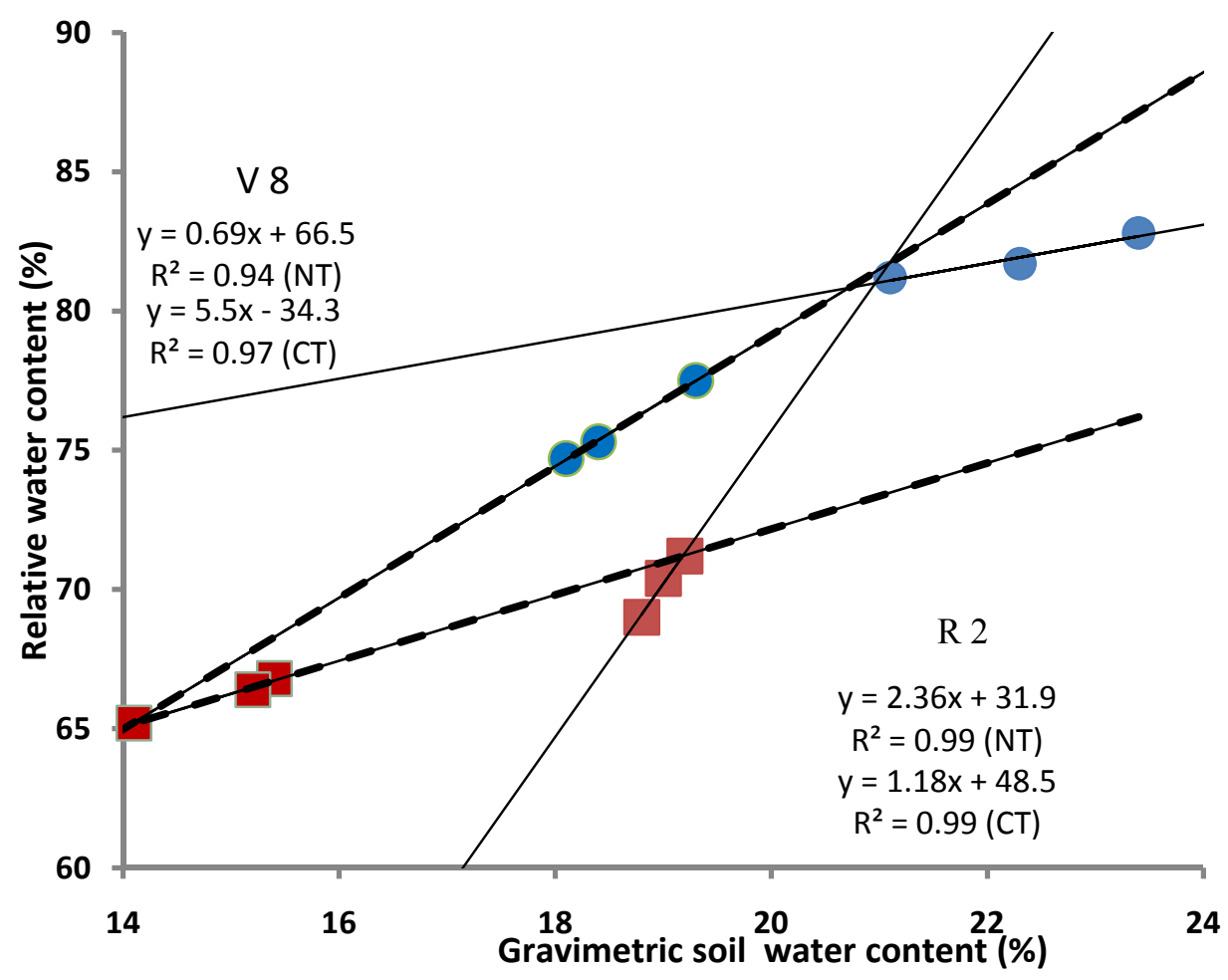

Figure 2. Relative water content (\%) as affected by no-till (circle markers), conventional tillage (square markers) and soil water content at V8 (solid lines) and R2 (dashed lines) growth stages

Changes in volumetric water content $(\theta)$ with depth among tillage practices during V8 and R2 growth stages (Figure 3) indicate that $\theta$ ranged from 0.22 to $0.34 \mathrm{~m}^{3} \mathrm{~m}^{-3}$ and 0.12 to $0.22 \mathrm{~m}^{3} \mathrm{~m}^{-3}$, respectively. More significant 
variations in $\theta$ among tillage treatments were observed during R2 than V8 growth stage (under drier soil condition).

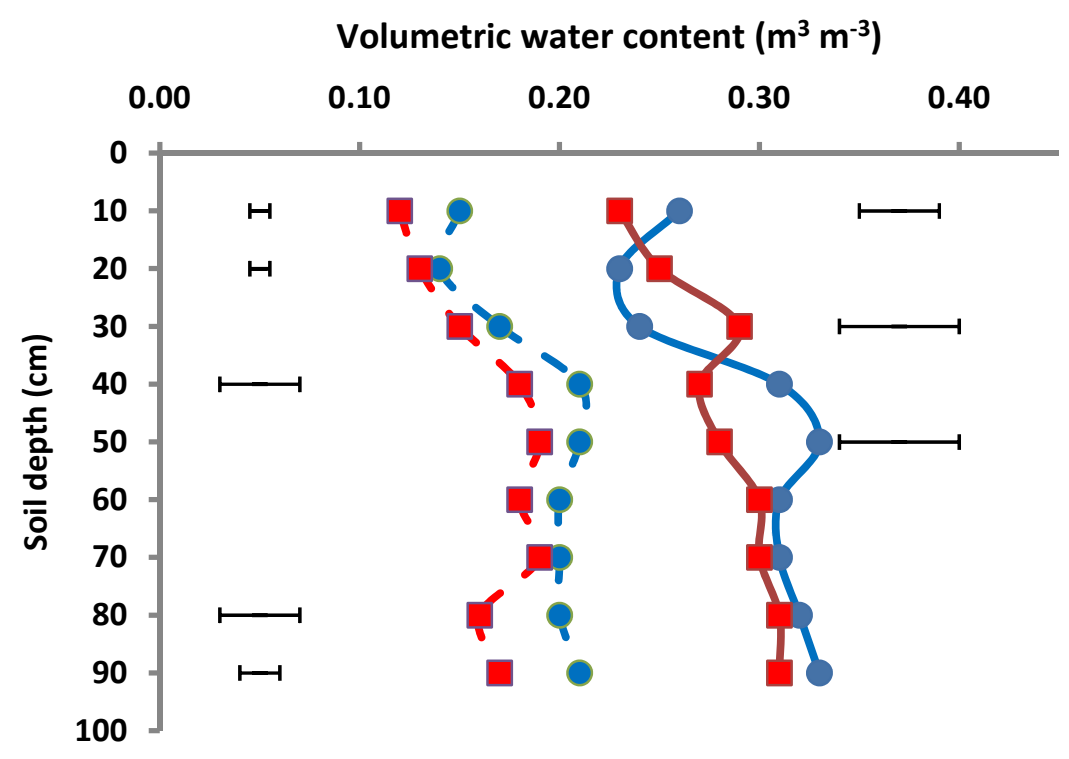

Figure 3. Volumetric soil water content as affected by no-till (circle markers), conventional tillage (square markers) and soil depth at V8 (solid lines) and R2 (dashed lines) growth stages. Bars show LSD $(<0.05)$ values

\subsection{Stomatal Closure as Affected by Tillage}

A significant variation in the proportionate decrease in RWC with increase in time after air drying of leaf discs was observed among both tillage treatments (Figure 4). Large and significant differences in RWC were observed at the beginning and the differences diminished towards the end of the experiment (i.e. after 240 minutes). The maximum variation in initial RWC was observed between NT (85.8 \%) and CT (79.3\%) during the V8 growth stage. A similar trend was observed but with lower values of RWC at R2 growth stage. Due to severe soil water stress during the R2 stage, stomata closed sooner in $\mathrm{CT}$ as was indicated by the constant RWC achieved earlier in CT than in NT.

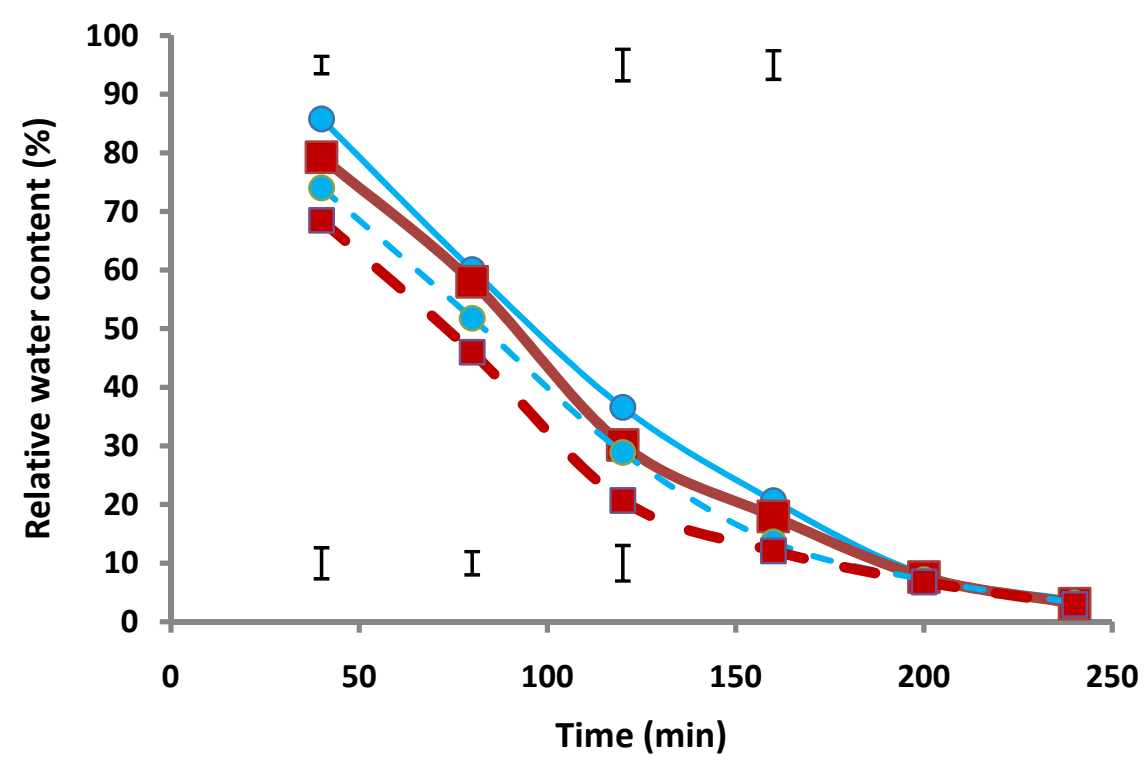

Figure 4. Proportionate decrease in relative water content as a function of time under no-till (circle markers) and conventional tillage (square markers) at V8 (solid lines) and R2 (dashed lines). Bars show LSD $(<0.05)$ values 


\subsection{Corn Root Distribution}

The RMD varied significantly $(\mathrm{P}<0.05)$ among tillage, soil depth and row positions (Tables $3 \& 4$ ). The RMD declined markedly with increase in soil depth beyond $30 \mathrm{~cm}$. Maximum RMD along the row for $0-10 \mathrm{~cm}$ depth was observed in NT $\left(0.50 \mathrm{Mg} \mathrm{m}^{-3}\right)$ and the least in CT $\left(0.34 \mathrm{Mg} \mathrm{m}^{-3}\right)$. Approximately $90 \%$ of total RMD occurred within the upper $50 \mathrm{~cm}$, and decreased with depth under NT (Figure 5). A higher RMD was observed for 10-20 cm depth in CT $\left(0.65 \mathrm{Mg} \mathrm{m}^{-3}\right)$ than in NT $\left(0.37 \mathrm{Mg} \mathrm{m}^{-3}\right)$. Similar observations were recorded across the row measurements. No significant differences in RMD were observed among tillage practices for both row positions below $30 \mathrm{~cm}$ depth. However, due to lesser water availability in the surface soil under CT, there was more root penetration into deeper layers in CT than in NT. For in-row measurements in the $60-90 \mathrm{~cm}$ depth, RMD varied from $0.014-0.107 \mathrm{Mg} \mathrm{m}^{-3}$ and $0.006-0.089 \mathrm{Mg} \mathrm{m}^{-3}$ under CT and NT, respectively. A similar trend was observed across the row measurement, except for relatively lesser values. There is a probable development of plow pan under CT, since higher bulk density and penetration resistance were measured in CT compared to those under NT (Figures 6 \& 7). However, among row positions, the maximum RMD was observed along rather than across the row. More significant $(\mathrm{P}<0.05)$ variations in percent RMD were observed in the upper than in lower soil layers. Further, RMD decreased by about $15 \%$ in across compared with along the row measurements. Further, RMD estimated through exponential equation (Equation 2) correlated well with the observed values (Figure 8). However, when the equation is modified (Equation 3) by adding the RMD values for the last depth, it over predicted the measured data by $15 \%$.

Table 3. Percent distribution of root mass density under different tillage systems along the row at different soil depths

\begin{tabular}{lccccccccc}
\hline Tillage practice & \multicolumn{10}{c}{ Soil depth $(\mathrm{cm})$} \\
\cline { 2 - 10 } & 10 & 20 & 30 & 40 & 50 & 60 & 70 & 80 & 90 \\
\hline NT & 35.3 & 21.9 & 18.1 & 9.6 & 5.4 & 4.2 & 2.4 & 2.2 & 0.9 \\
CT & 20.1 & 35.9 & 13.4 & 12.3 & 5.0 & 5.2 & 5.0 & 2.0 & 1.1 \\
LSD $(\mathrm{P}<0.05)$ & 1.9 & 2.5 & 2.3 & NS & NS & NS & 0.4 & NS & NS \\
\hline
\end{tabular}

$(\mathrm{NT}=$ no-till $; \mathrm{CT}=$ conventional tillage $)$

Table 4. Percent distribution of root mass density under different tillage systems across the row at different soil depths

\begin{tabular}{lccccccccc}
\hline Tillage practice & \multicolumn{10}{c}{ Soil depth $(\mathrm{cm})$} \\
\cline { 2 - 11 } & 10 & 20 & 30 & 40 & 50 & 60 & 70 & 80 & 90 \\
\hline NT & 30.2 & 22.9 & 13.2 & 12.2 & 10.3 & 4.8 & 3.9 & 2.0 & 0.6 \\
CT & 19.4 & 37.3 & 11.5 & 7.9 & 9.5 & 6.2 & 4.6 & 2.8 & 0.8 \\
LSD $(\mathrm{P}<0.05)$ & 4.5 & 6.2 & NS & 3.2 & NS & 1.2 & NS & NS & NS \\
\hline
\end{tabular}

(NT= no-till; $\mathrm{CT}=$ conventional tillage $)$ 


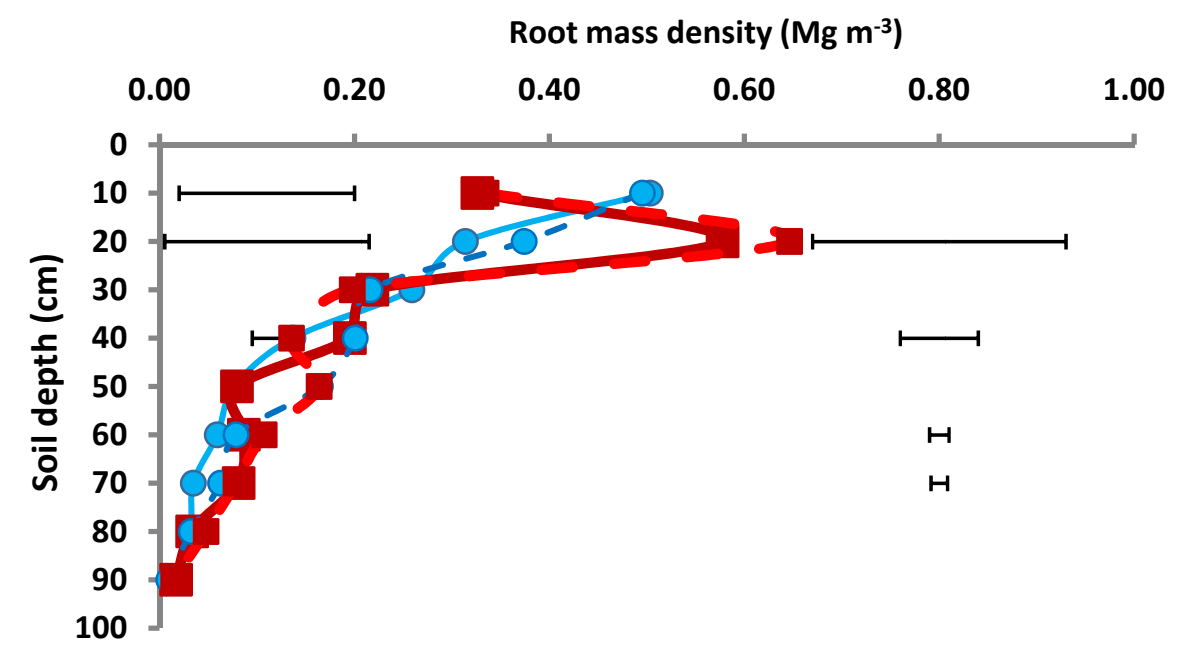

Figure 5. Root mass density as affected by no-till (circle markers) and conventional tillage (square markers) across (solid line) and along (dashed line) the row. Bars show LSD $(<0.05)$ values.

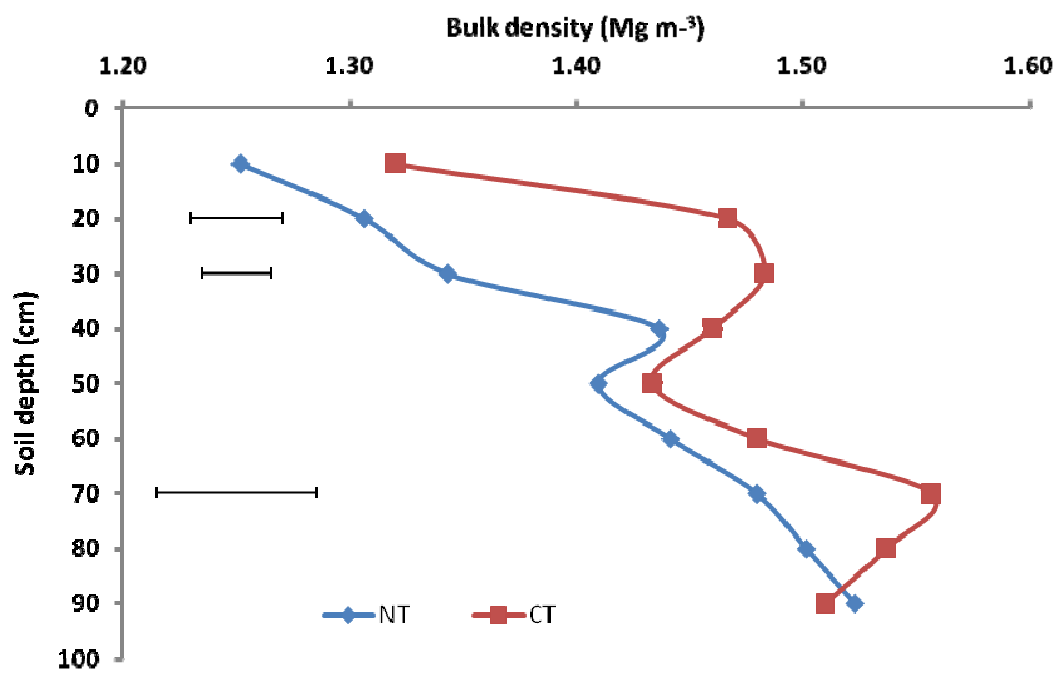

Figure 6. Soil bulk density as affected by different tillage practices. Bars show LSD $(<0.05)$ values

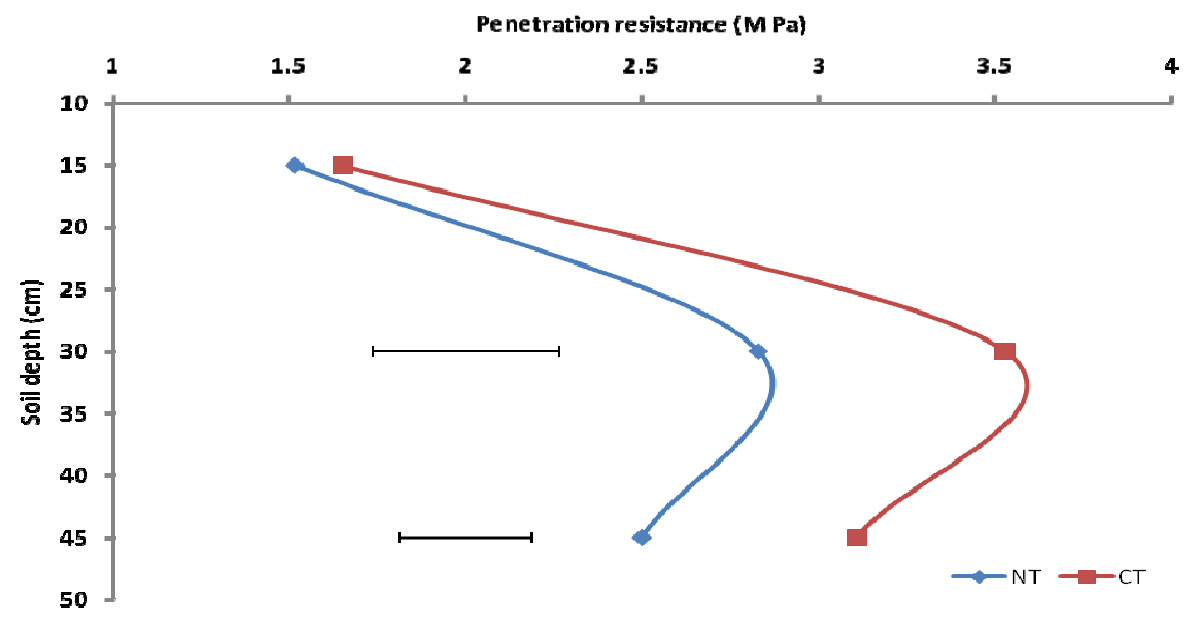

Figure 7. Penetration resistance as affected by different tillage practices. Bars show $\operatorname{LSD}(<0.05)$ values 


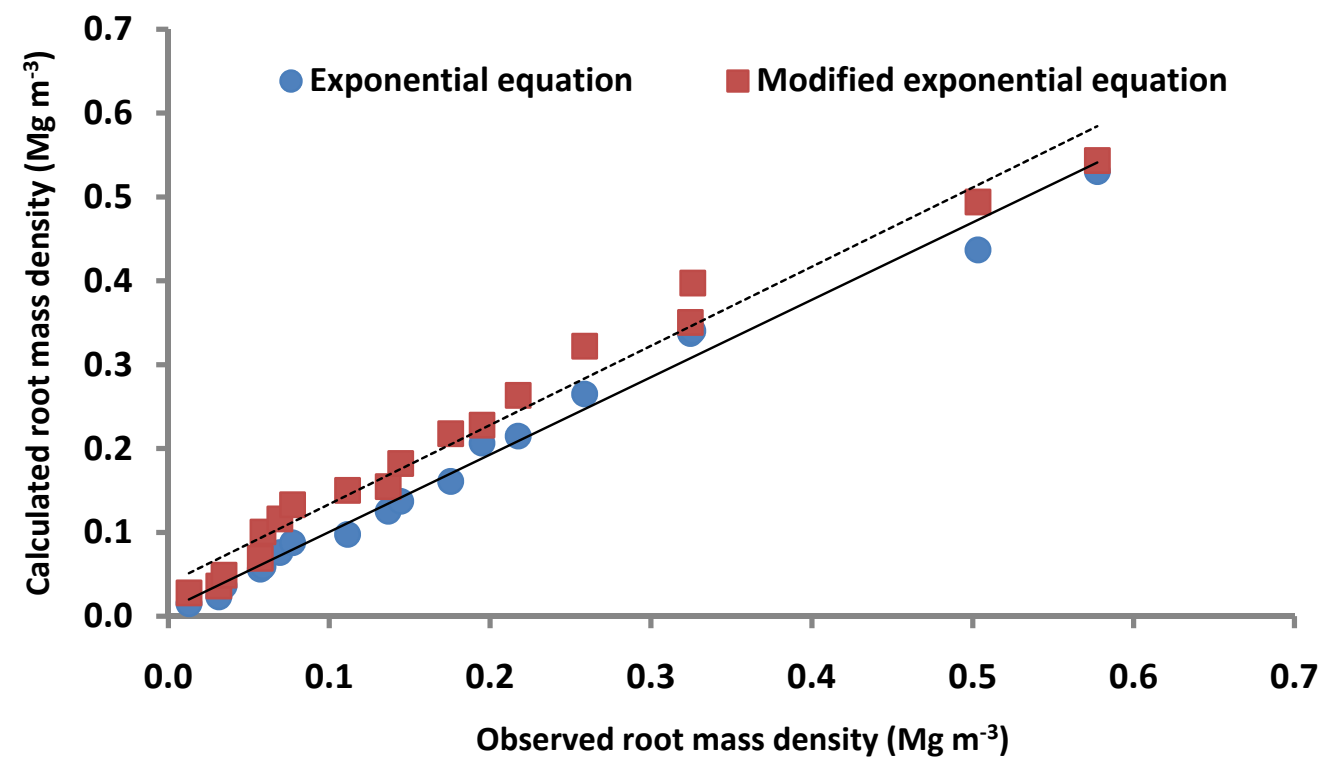

Figure 8. Calculated values of root mass density through exponential equation (solid line) and modified exponential equation (dashed line) against observed values

\subsection{Volumetric Water Content $(\theta)$}

The data on $\theta$ as affected by the date of sampling, soil depth, and tillage treatment (Figure 9) indicate that $\theta$ was significantly affected by tillage $(\mathrm{P}<0.05)$. The maximum variation in $\theta$ was observed under NT $(0.28-0.39)$ and the least under CT (0.12-0.19) throughout the soil profile under the wettest and the driest periods of the cropping season, respectively. Further, $\theta$ varied more significantly among tillage treatments during the dry periods throughout the soil profile. In general, $\theta$ increased with increase in soil depth up to $50 \mathrm{~cm}$ and it decreased with depth thereafter. Among tillage treatments, significantly $(\mathrm{P}<0.05)$ higher $\theta$ was observed in surface soil under NT for most of the sampling dates. Significant temporal variations in $\theta$ were observed during the cropping season (Figure 9).

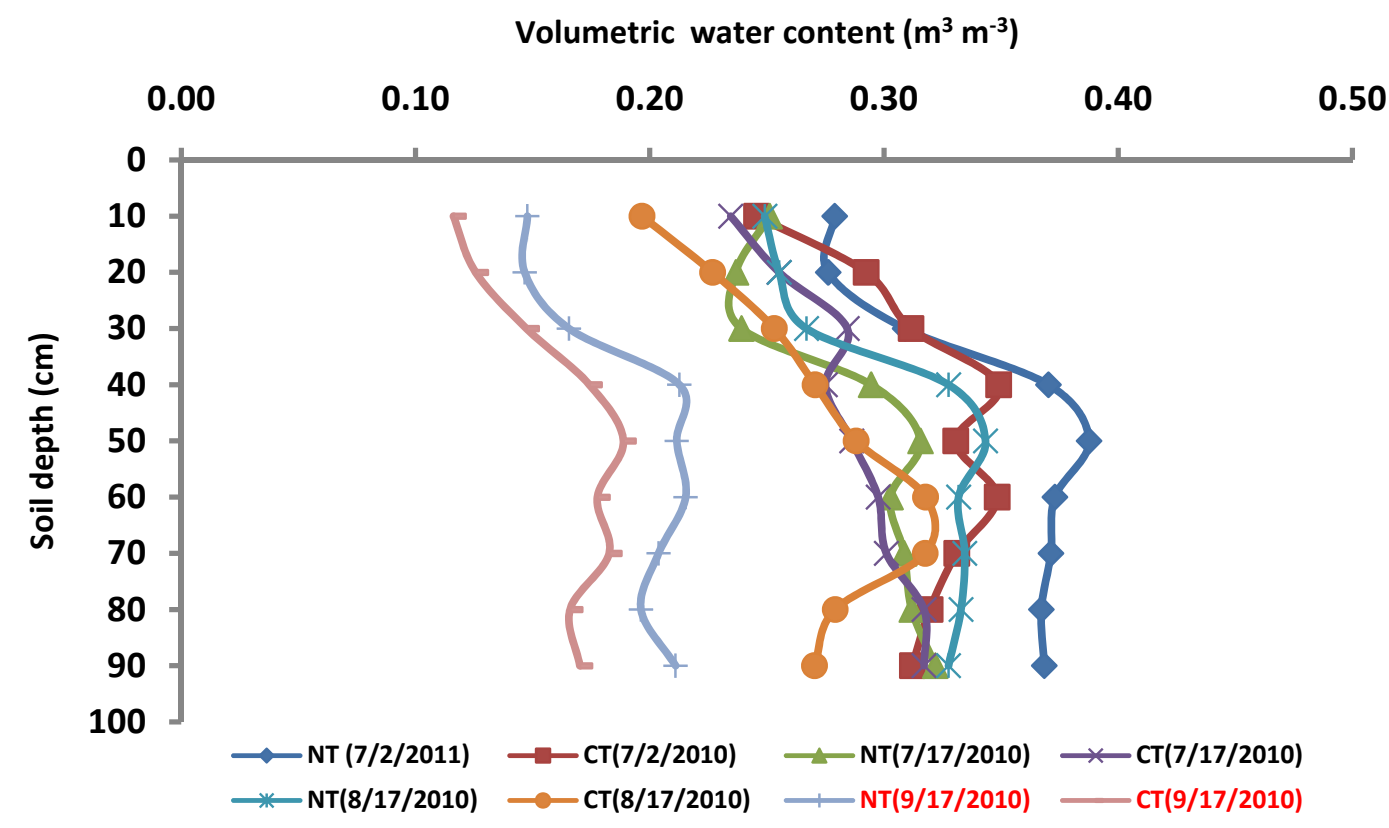

Figure 9. Volumetric soil moisture content as affected by different tillage practices, soil depth and time of measurement 


\section{Discussion}

Tillage significantly affects soil mechanical and hydrological properties, which subsequently affect plant growth parameters, particularly root growth and water uptake. Soil water availability and mechanical impedance are the two main parameters that directly affect plant growth and biomass. The data obtained in the present study indicates that tillage significantly $(\mathrm{P}<0.05)$ affects RWC, stomatal closure and RMD. The higher soil water content measured under NT increased RWC, while the lower soil water reserves under CT decreased RWC. Further, there were considerable variations in RWC within treatment for the measurements made during different times of the day. A sharp decline in RWC was observed in CT for the measurements made at $1400 \mathrm{hrs}$ and 1700 hrs. Similar observations were also reported by Zhang et al. (2008), probably because of a higher evaporative demand and lesser availability during the afternoon. Zhang and colleagues also observed that a higher leaf temperature than ambient temperature under CT than NT may be another reason for this response of RWC. Lower RWC under CT indicated that corn plants were subjected to higher degree of drought stress than those under NT. Thus, plants grown under NT system were better able to meet the transpiration demand than those under CT. Further, the reduction in transpiration was less under NT than under CT. The early morning RWC measurements in this study followed the same trend as did the soil water reserves. Li-Ping et al. (2006) observed that RWC of corn was reduced from $92.8 \%$ to $79.9 \%$ under adequate water to severely stressed conditions at silking stage of corn growth. The ultimate destination for most of the soil water moving into a plant is the leaf surface, where it is lost as vapor through the stomatal pores. The driving force to move the liquid water from the root to the leaf is the water potential gradient. The RWC decreased significantly with decrease in soil matric potential $(\Phi)$. Crop growth may be reduced by increasing compaction of soil, limiting the volume of soil water accessible to the plant, as well as the overall lack of water. The RMD is higher under NT in surface soil due to more availability of water and nutrients in this soil layer. Also, the extensive colonization of the root areas under NT indicates that the quality and structure of soil may have improved under NT. For better root proliferation to lower soil depth there is a need to check hard pan formation, so that roots can extract more nutrients and water from the sub soil. Roots in CT did not penetrate into the soil below this depth because of the hard soil layer (plow pan) as indicated by high bulk density and PR measurements. The maximum PR was observed under CT $(3.52 \mathrm{M} \mathrm{Pa})$ and the least under NT $(2.83 \mathrm{M} \mathrm{Pa})$ at $15-30 \mathrm{~cm}$ depths (Figure 7). In the surface soil layer, there was no significant difference in PR among tillage treatments. In general, $\mathrm{PR}$ increased significantly $(\mathrm{P}<0.05)$ with increase in depth for all treatments, particularly for the CT treatment. The differences in PR among treatments were more drastic beneath $30 \mathrm{~cm}$ depth. Stewart et al. (1999) also observed that up to $80 \%$ of roots were located in and around the macropores. However, among row positions, the maximum RMD was observed along than across the row. The present results of a higher RMD closer to the row were also reported in earlier studies (Liedgens \& Richner, 2001; Qin et al., 2004; Qin et al., 2006). There were few roots below $50 \mathrm{~cm}$ depth. Similar, observations were also recorded by Dowdy et al. (1993) and Qin et al. (2006). Since there was an adequate soil water for crop growth in the top $60 \mathrm{~cm}$ soil profile, hence a shallow rooting depth was adequate. Ball-Coelho et al. (1998) reported that root length density in the top $10 \mathrm{~cm}$ of soil depth was higher under NT $\left(17 \mathrm{~km} \mathrm{~m}^{-3}\right)$ than CT $\left(7 \mathrm{~km} \mathrm{~m}^{-3}\right)$, while in the 15 to $30 \mathrm{~cm}$ layer it was $4 \mathrm{~km} \mathrm{~m}^{-3}$ lower under NT than CT. The root weight was distributed more horizontally under NT than $\mathrm{CT}$, which shows that both equations could be used for estimating the RMD under different tillage practices if rooting depth and root mass density at the surface layer are known (Dwyer et al., 1995).

\section{Conclusions}

The data presented support the following conclusions:

- Higher soil water content was observed throughout the soil profile under no-till than conventional tillage. However, bulk density and penetration resistance were observed to be more in the sub-surface soil layer under conventional till than those under no-till.

- $\quad$ No-till maintains significantly higher relative water content of corn leaves even during drought conditions due to high soil water reserves as compared to conventional tillage.

- Under drought conditions, stomata close much earlier under conventional tillage than under no-till treatment.

- Tillage also significantly impacts root mass distribution: higher root mass density observed in the surface soil layer under no-till may be due to higher soil water content than in conventional tillage. Formation of plow pan in conventional tillage restricted root growth to the surface layer, thus plants were subjected to drought stress more than those grown in no-till system. 


\section{Acknowledgments}

The authors are grateful to Punjab Agricultural University, Ludhiana for the financial support to undertake the work at Ohio State University. We thanks the staff of OSU/ OARDC, Piketon for the technical, field and laboratory help in successfully conducting the experiment, providing equipments and analyzing the soil samples.

\section{References}

Amato, M., \& Ritchie, J. T. (2002). Spatial distribution of roots and water uptake of maize (Zea mays L.) as affected by soil structure. Crop Sci., 42, 773-780.

Aminzadeh, G. A., \& Eshghi, G. (2006). Evaluation of drought resistance in new lines and cultivars of bread wheat. (Abstract). The first international conference on the theory and practices in biological water saving (ICTPB), 21-25 May, Beijing, China.

Ball-Coelho, B. R., Roy, R. C., \& Swanton, C. J. (1998). Tillage alters corn root distribution in coarse-textured soil. Soil Till. Res., 45, 237-249.

Barber, S. A., \& Kovar, J. L., (1991). Effect of tillage practice on maize (Zea mays L.) root distribution. Pages 402-409 in McMichael BL, Parsson H, eds. Developments in Agricultural and Managed-forest Ecology, 24. New York, NY. Elsevier Press.

Barrs, H. D. (1968). Determination of water deficits in plant tissues. In T. T. Kozlowski, ed. Water Deficits and Plant Growth (Vol. 1, pp. 235-368). Academic Press. New York.

Barrs, H. D., \& Weatherley, P. E. (1962). A re-examination of the relative turgidity technique for estimating water deficits in leaves. Aus. J. Biol. Sci., 15, 413-428.

Bengough, A. G., McKenZie, B. M., Hallett, P. D., \& Valentine, T. A. (2011). Root elongation, water stress, and mechanical impedance: a review of limiting stresses and beneficial root tip traits. J. Exp. Bot., 62, 59-68.

Bhattacharyya, R. S., Kundu, S. C., Pandey, K. P., Singh, \& Gupta, H. S. (2008). Tillage and irrigation effects on crop yields and soil properties under the rice-wheat system in the Indian Himalayas. Agric. Water Manage, 95, 993-1002.

Blake, G. R., \& Hartge, K. H. (1986). Bulk density. In Klute, A. (Ed.), Methods of Soil Analysis. Part I. Physical and Mineralogical Methods, second ed. Agronomy Monograph No 9. ASA and SSSA, Madison, WI, pp. 363-382.

Cheema, S. S., \& Singh, B. (1990). CPCS1: A computer programs package for the analysis of commonly used experimental designs. Punjab Agricultural University, Ludhiana, India.

Diaz-Zorita, M., Duarte, G., \& Grove, J. (2002). A review of notill systems and soil management for sustainable crop production in the sub-humid and semi-arid Pampas of Argentina. Soil Till. Res., 65, 1-18.

Diaz-Zorita, M., Grove, J. H., \& Perfect, E. (2005). Soil fragment size distribution and compactive effort effects on maize root seedling elongation in moist soil. Soil Sci. Soc. Am. J., 45, 1417-1426.

De Vita, P., Di Paolo, E., Fecondo, G., Di Fonzo, N., Pisante, M. (2007). No-tillage and conventional tillage effects on durum wheat yield, grain quality and soil moisture content in southern Italy. Soil Till. Res., 92, 69-78.

Dowdy, R. H., Linden, D. R., Dolan, M. S., \& Allmras, R. R. (1993). Impact of tillage on maize rooting patterns. In Root Ecology and Its Practical Application. Eds. Kutschera, L., Hubl, E., Lichtenegger, E., Persson, H., Sobotik, M. pp. 401-404. Verein für Wurzelforschung, Klagenfurt, Austria.

Duruoha, C., Piffer, C. R., \& Silva, P. A. (2007). Corn (Zea mays L.) root length density and root diameter as affected by soil compaction and soil water content. Irrigation, 12, 14-26.

Dwyer, L. M., Ma, B. L., Stewart, D. W., Hayhoe, H. N., Balchin, D., Culley, J. L. B., \& McGovern, M. (1995). Root mass distribution under conventional and conservation tillage. Can. J. Soil Sci., 76, 23-28.

Dwyer, L. M., Stewart, D. W., \& Balchin, D. (1988). Rooting characteristics of corn, soybeans and barley as a function of available water and soil physical characteristics. Can. J. Soil Sci., 68, 121-132.

Esparza-Rivera, J. R., Stone, M. B., Stuchnoff, C., Pilon-Smits, E., \& Kendall, P. A. (2006). Effects of ascorbic acid applied by two hydrocooling methods on physical and chemical properties of green leaf stored at $5{ }^{\circ} \mathrm{C}$. J. Food Sci., 71, 270-276. 
Ferrat, I. L., \& Lovatt, C. J. (1999). Relationship between relative water content, nitrogen pools and growth of Phaseolus vulgaris L. and P. acutifolius A. Grag during water deficit. Crop Sci., 39, 467-475.

Flexas, J., Ribas-Carbo, M., Bota, J., Galmes, J., Henkle, M., Martinez-Canellas, S., \& Medrano, H. (2006). Decreased Rubisco activity during water stress is not induced by decreased relative water content but related to conditions of low stomatal conductance and chloroplast $\mathrm{CO}_{2}$ concentration. New Phytol., 172, $73-82$.

Gonzalez, L., \& Gonzalez-Vilar, M. (2001). Determination of relative water content. In Reigosa MJ (ed) Handbook of Plant Ecophysiology Techniques (pp. 207-211). Kluwer Academic Publisher, Dordrecht.

Gutierrez, M., Matthew, P. R., \& Klatt, A. R. (2010). Association of water spectral indices with plant and soil water relations in contrasting wheat genotypes. J. Exp. Bot., 6, 3291-3303.

He, J., Li, H. W., \& Gao, H. W. (2006). Subsoiling effect and economic benefit under conservation tillage mode in Northern China. Trans. CSAE, 22, 62-67 (in Chinese).

Himmelbauer, M. L., L. H., Loiskandl, W., \& Rousseva, S. (2010). Spatial root distribution and water uptake of maize grown field with subsoil compaction. J Hydr. Hydromech, 58, 163-174.

Hossain, M. I., Osaki, M., Haque, M. S., Khan, M. M. H., Rahmatullah, N. M., \& Rashid, M. H. (2008). Effect of straw management and nitrogen fertilization on root growth and root characteristics of wheat through raised bed system on a low N calcareous soil of Bangladesh. Thai. J. Agri. Sci., 41, 45-52.

Hughes, K. A., Horne, D. J., Ross, C. W., \& Julian, J. F. (1992). A 10-year maize/oats rotation under three tillage systems: 2. Plant population, root distribution and forage yields. Soil Till. Res., 22, 145-157.

Iijima, M., Satoru, M., Walter, Zegada-Lizarazu, \& Yasuhiro, I. (2007). No-tillage enhanced the dependence on surface irrigation water in wheat and soyabean. Plant Prod. Sci., 10, 182-188.

Karunatilake, U., Van Es, H. M., \& Schindelbeck, R. R. (2000). Soil and maize response to plow and no-tillage after alfalfa-to-maize conversion on a clay loam soil in New York. Soil Till. Res., 55, 31-42.

Khan, H. R., \& Stoddard, F. L. (2005). Genotype variation physiological attributes related to drought tolerance in faba bean. (Abstract) The 2nd International Conference on Integrated Approaches to Sustain and Improve Plant Production Under Drought Stress. Inter, Drought-II. September 24 to 28. Rome-Italy.

Kirkham, M. B. (2005). Principles of soil and plant water relations. Elsevier Academic Press, Burlington, Massachusetts, USA.

Keyvan, S. (2010). The effects of drought stress on yield, relative water content, proline, soluble carbohydrates and chlorophyll of bread wheat cultivars. J. Anim. Plant Sci., 8, 1051-1060.

Kramer, P. J., \& Boyer, J. S. (1995). Water Relations of Plants and Soils. San Diego. Academic Press.

Kumar, R., \& Kujur, R. (2003). Role of secondary traits in improving the drought tolerance during flowering stage in rice. Ind. J. Plant Physiol., 8, 236-240.

Lahai, M. T., \& Ekanayake, I. J. (2009). Accumulation and distribution of dry matter in relation to root yield of cassava under a fluctuating water table in inland valley ecology. Afri. J. Bio., 8, 4895-4905.

Liedgens, M., \& Richner, W. (2001). Minirhizotron observations of spatial distribution of the maize root system. Agron. J., 93, 1097-1104.

Li-Ping, B., Fang-Gong, G., Zhao-Hui, S., Yin-Yan, L., \& Guang-Sheng, Z. (2006). Effects of soil draught stress on leaf water status, membrane permeability and enzymatic antioxidant system of maize. Pedosphere, 16, 326-332.

Logsdon, S. D., \& Allmaras, R. R. (1991). Maize and soybean root clustering as indicated by root mapping. Plant Soil, 131, 169-176.

Malarvizhi, D., Thiyagarajan, K., Vijayalakshmi, C., \& Manonmani, S. (2010). Genetic analysis to assess the physiological efficiency of parental lines in rice (Oryza Sativa L). Electronic J. Pl. Breeding, 1, 100-113.

Martinez, E., Juan-Pablo, F., Silva, P., Susana, Valle., \& Edmundo, A. (2008). Soil physical properties and wheat root growth as affected by no-tillage and conventional tillage systems in a Mediterranean environment of Chile. Soil Till. Res., 99, 232-244.

McGonigle, T. P., \& Miller, M. H. (1996). Mycorrhizae, phosphorus absorption, and yield of maize in response to tillage. Soil Sci. Soc. Am. J., 60, 1856-1861. 
McKenzie, B. M., Bengough, A. G., Hallett, P. D., Thomas, W. T. B., Forster, B., \& McNicol, J. W. (2009). Deep rooting and drought screening of cereal crops: a novel field-based method and its application. Field Crops Res., 112, 165-171.

Micucci, F. G., \& Taboada, M. A. (2006). Soil physical properties and soybean (Glycine max Merrill) root abundance in conventionally-and zero-tilled soils in the humid Pampas of Argentina. Soil Till. Res., 86, 152-162.

Newell, R. L., \& Wilhem, W. W. (1987). Conservation tillage and irrigation effects on corn root development. Agron. J., 79, 160-165.

Neyestani, E., \& Azimzadeh, M. (2003). Study of drought tolerance of 15 lentil varieties. Iranian J. Agric., 5, 61-69.

Pennisi, E. (2008). Plant genetics: the blue revolution, drop by drop, gene by gene. Sci., 320, 171-173.

Qin, R. J., Stamp, P., \& Richner, W. (2004). Impact of tillage on root systems of winter wheat. Agron. J., 96, 1523-1530.

Qin, R. J., Stamp, P., \& Richner, W. (2006). Impact of tillage on maize in a cambisol and luvisol in Switzerland. Soil Till. Res., 85, 50-61.

Raczkowski, C. W. (1988). Effects of four tillage systems on corn (Zea mays L.) root distribution in the North Carolina Piedmont. Ph.D. thesis DA8909228. North Carolina State University, Raleigh, NC.

Siddique, M. R. B., Hamid, A., \& Islam, M. S. (2000). Drought stress effects on water relations of wheat. Bot. Bull. Acad. Sin., 41, 35-39.

Stewart, J. B., Moran, C. J., \& Wood, J. T. (1999). Macropore sheath: quantification of plant root and soil macropore association. Plant Soil, 211, 59-67.

Tardieu, F. (1994). Growth and functioning of roots and of root systems subjected to soil compaction. Towards a system with multiple signaling. Soil Till. Res., 30, 217-243.

Tatar, O., \& Gevrek, M. N. (2008). Influence of water stress on proline accumulation, lipid peroxidattion and water control of wheat. Asian J. Pl. Sci., 1, 1-4.

Taboada, M. A., \& Alvarez, C. R. (2008). Root abundance of maize in conventionally tilled and zero tilled soils of Argentina. R Bras. Ci. Solo., 32, 769-779.

Vyn, T. J., (2008). Tillage and fertility placement aspects of root zone optimization for corn. www.agry.purdue.edu/staffbio/tillage $\% 20$.

Weatherley, P. E. (1950). Studies in the water relations of the cotton plant. I. The field measurement of water deficits in leaves. New Phlytol., 49, 81-97.

Weatherley, P. E. (1951). Studies of the water relations of the cotton plant. II. Diurnal and seasonal variations in relative turgidity and environmental factors. New Phytol., 50, 36-51.

Whalley, W. R., Leeds-Harrison, P. B., Clark, L. J., \& Gowing, D. J. G. (2005). Use of effective stress to predict the penetrometer resistance of unsaturated agricultural soils. Soil Till. Res., 84, 18-27.

Whitmore, A. P., \& Whalley, W. R. (2009). Physical effects of soil drying on roots and crop growth. J. Exp. Bot., 60, 2845-2857.

White, R. G., \& Kirkegaard, J. A. (2010). The distribution and abundance of wheat roots in a dense, structured subsoil-implications for water uptake. Plant Cell Envir., 33, 133-148.

Yamaguchi, M., \& Sharp, R. E. (2010). Complexity and coordination of root growth at low water potentials: recent advances from transcriptomic and proteomic analyses. Plant Cell Envir., 33, 590-603.

Zhang, M., Zhang, R. Z., \& Cai, L. Q. (2008). Leaf water potential of spring wheat and field pea under different tillage patterns and its relationship with environmental factors. Ying Yong Sheang Tai Xue Bao, 19, $1467-74$. 